Article

\title{
Sustainable Transportation and Policy Development: A Study for Impact Analysis of Mobility Patterns and Neighborhood Assessment of Walking Behavior
}

\author{
Gustavo de Siqueira ${ }^{1, * \mathbb{C}}$, Ahmad Adeel ${ }^{1,2}$, Petrit Pasha ${ }^{1}$, Amal Al Balushi ${ }^{1}{ }^{\mathbb{D}}$ and Syyed Adnan Raheel Shah ${ }^{3,4}$ \\ 1 Department of Urban Planning and Architectural Design, German University of Technology, \\ Muscat 130, Oman; ahmad.adeel@kuleuven.be (A.A.); petrit.pasha@gutech.edu.om (P.P.); \\ amalalbalushi@hotmail.com (A.A.B.) \\ 2 Department of Architecture, Katholieke Universiteit Leuven (KU Leuven), 3001 Heverlee, Belgium \\ 3 Department of Civil Engineering, Pakistan Institute of Engineering and Technology, Multan 60000, Pakistan; \\ syyed.adnanraheelshah@uhasselt.be \\ 4 Instituut Voor Mobiliteit, Universiteit Hasselt, 3590 Diepenbeek, Belgium \\ * Correspondence: Gustavo.desiqueira@gutech.edu.om
}

Citation: Siqueira, G.d.; Adeel, A.; Pasha, P.; Balushi, A.A.; Shah, S.A.R. Sustainable Transportation and Policy Development: A Study for Impact Analysis of Mobility Patterns and Neighborhood Assessment of Walking Behavior. Sustainability 2021, 13, 1871. https://doi.org/10.3390/ su13041871

Academic Editor: Long T. Truong

Received: 15 December 2020

Accepted: 30 January 2021

Published: 9 February 2021

Publisher's Note: MDPI stays neutral with regard to jurisdictional claims in published maps and institutional affiliations.

Copyright: (c) 2021 by the authors. Licensee MDPI, Basel, Switzerland. This article is an open access article distributed under the terms and conditions of the Creative Commons Attribution (CC BY) license (https:// creativecommons.org/licenses/by/ $4.0 /)$.

\begin{abstract}
Since rapid growth and car-oriented patterns became a global threat and non-communicable diseases (NCDs) levels are advancing, strategies to redesign the built environment into healthier spaces have gained importance. Walkability plays a central role in this context. However, the literature is dominated by studies from western industrialized countries. In this paper, we employed structural equational modeling to analyze perceptual data collected from different neighborhoods of Muscat. We compared the responses regarding environmental attributes to the frequency of walking for transport. We found that land use mix combined with low residential density are the factors that have the highest impact on pedestrian activity. Conversely, the estimates of the pedestrian infrastructure were surprisingly low, suggesting that, in car dominant societies, walking perceptions are affected by drivers' perspectives.
\end{abstract}

Keywords: sustainability; transport; urban planning; mobility; walking; neighborhood

\section{Introduction}

The conventional development of suburbs and urban sprawl has been broadly discouraged, as it degrades the social environment. They restrict opportunities for interacting with neighbors and hinder them from psychologically bonding with their communities [1,2]. Consequently, mixed-use, high density, and pedestrian-oriented developments have been emphasized by the new urbanist agenda as mechanisms to boost the sense of community, along with various other benefits. A large body of research investigates the association between physical characteristics of the built environment and neighborhood outcomes, such as physical activity and social aspects. Some studies have compared suburban areas with pedestrian-oriented kinds of development and have discovered higher levels of a sense of community, health, and well-being in the latter [3,4].

In terms of design, comprehensive research has been carried out based on perceived environmental assessment, using widely tested and well-proven tools for subjective assessments [5,6]. Other studies have employed objective assessments or mixed-mode methodologies, combining GIS data and physical activity measurements with accelerometers [7,8]. Despite the availability of data and sophistication of methods, discrepancies between the results of studies on perceived and objectively measured factors persist $[9,10]$. This indicates a demand for further methodological investigations.

The research on walkable environments has evolved substantially in the last 20 years. It has become an essential element in informing policies for the sustainable urbanization 
of Western societies (Figure 1). Perceived environmental tools, in particular, have recently gained ground for adaptions in developing countries with emergent economies [11].
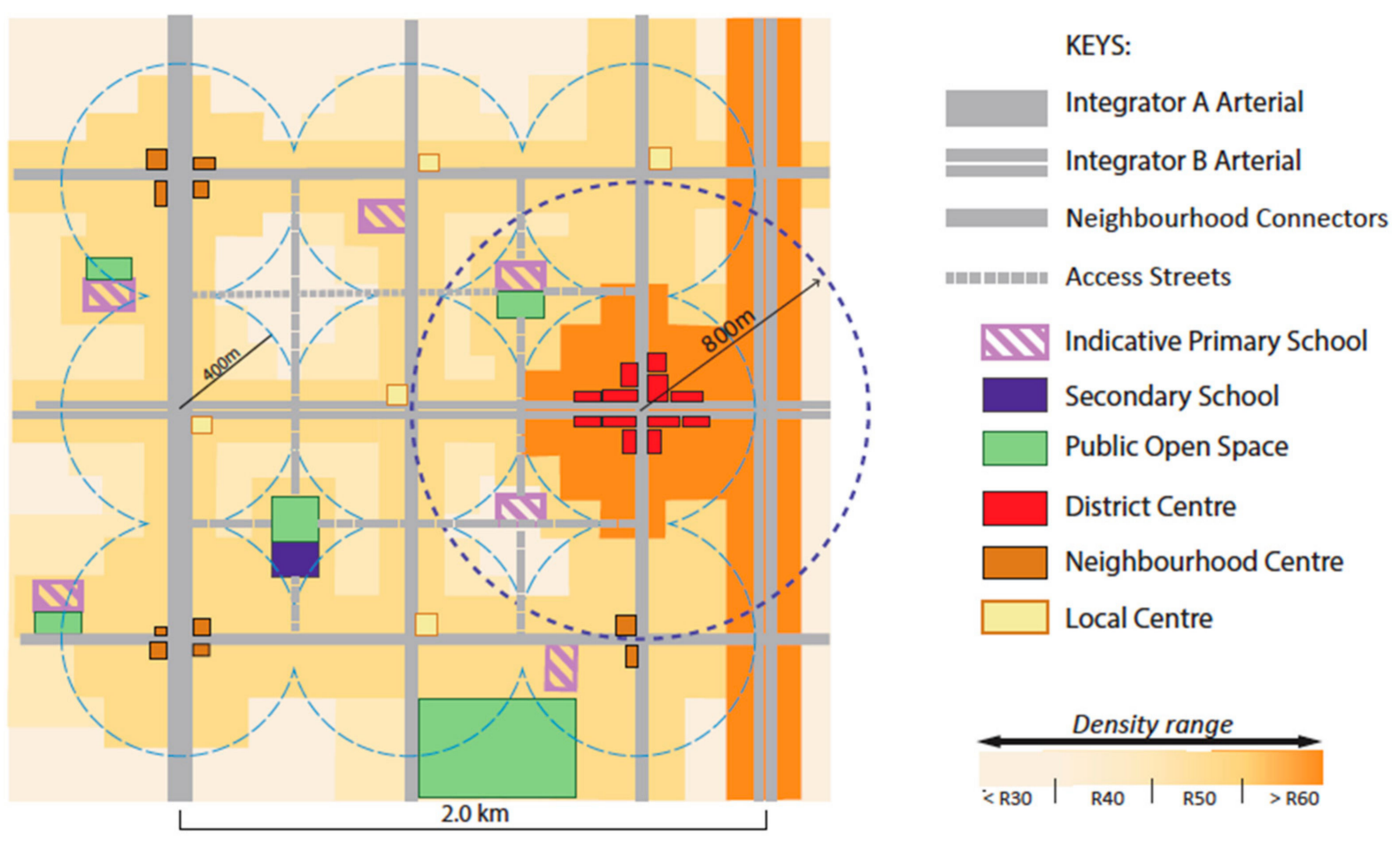

Figure 1. Policies to create dense and mixed walkable cores to make suburbs more livable [12].

In Oman, similarly to other countries in the region, the combination of nearly universal car ownership and a lack of adequate urban infrastructures poses challenges to pedestrian activity without precedent. In this paper, we employed an alternative statistical method to explore methodological limitations for assessing this context. The results will help to develop recommendations for similar situations internationally.

\section{Background}

Urbanization plays a central role in the United Nations Sustainable Development Goals. There are 2 items (3 - Good Health and Wellbeing, and 11-Sustainable Cities and Communities) out of 17 that are directly linked to Urban Planning [13]. It is not surprising, since sustainably planned environments, especially walkable cities, are widely recognized as more efficient than their car-oriented counterparts. Authors have shown that walkable environments help to create more compact growth, reducing land consumption and encroachments [14]. Further, increased walkability is associated with a decrease in the number of travelers $[15,16]$, which contributes to the reduction of energy consumption and emissions [17]. Walkability also has a direct correlation with higher levels of physical activity, actively promoting health and wellbeing [18-20]. Additionally, it has a significant impact on the social aspects of the neighborhoods where they are in place $[3,21]$ and helps to boost the local economy [22], making neighborhoods more resilient and reducing inequities [23]. Therefore, turning cities into more walkable environments is, in general, a relevant agenda to increase sustainability and a crucial factor to meet the United Nations Sustainable Development Goals (SDGs). Since Jacobs [24] defined the basic principles for lively cities, a growing agenda under the slogan "new urbanism" has been established [25]. Scholars have compared neighborhoods entailing new urbanist features and found that they perform better in many aspects, such as health outcomes, predominantly associated with higher degrees of pedestrian activity [26,27]. Environmental attributes-usually associated with walkable and lively neighborhoods—are the so-called "3 Ds": Density, Diversity (land use 
and incomes), and Design (street network and general environmental features, including setbacks, street width, street lights, etc.) [28]. Walkability has a central role in the new urbanism agenda and related approaches, such as "smart growth".

Global projections for 2030 [29] indicate rising numbers of non-communicable diseases (NCDs) (target 3.4 of the UN SDGs), while infectious diseases are decreasing. Generally, low levels of physical activity and unhealthy lifestyles are regarded as the main determinants of the growth in NCDs and, therefore, the primary causes of premature deaths worldwide. Thus, the World Health Organization launched a global action plan to combat non-communicable diseases. Their goals include a $10 \%$ reduction of insufficient physical activity levels and a $25 \%$ reduction in mortality by cardiovascular diseases. Additionally, it aims to hinder the rise of diabetes and obesity levels. Particularly, in Oman, the levels of NCDs are very high and rising at an accelerated pace [30-33]. Currently, NCDs claim approximately $70 \%$ of the total premature deaths in Oman, while over $80 \%$ of young Omanis are not sufficiently engaged in physical activities and one-quarter of the adult population is obese. Consequently, the Ministry of Health of Oman has issued a strategy to combat non-communicable diseases within the agenda of the Health Vision for Oman [33]. Healthier habits and active environments are becoming central development targets for Oman and other countries in the region. The health benefits associated with higher degrees of walkability are undisputed. Studies in the field are often focused on the increase of the physical activity levels or other health estimates as a correlate to different walkingrelated environmental attributes combined. Some authors operationalize physical activity as Body Mass Index [34], while others use the frequency of transport, recreational walking, cycling, and sitting time $[35,36]$. The International Physical Activity and the Environment Network project (IPEN) was launched in 2004 as a research network aiming to increase research activity, develop methodologies, and boost collaboration among scholars studying walkability [37]. A comprehensive study was conducted, pooling results from projects that originated in 12 countries [38]. The study compared perceived environmental attributes (independent variables) against the level of physical activity (dependent variable). For the first, they employed the Neighborhood Environmental Walkable Scale tool [5], and for the latter, the International Physical Activity Questionnaire [39].

Informed by the theories of walkable cities and in line with the methodologies developed by the IPEN research agenda, the authors analyzed comprehensive data collected locally and drew recommendations for planning policies for the development of casesensitive tools valid for an international context. We are convinced that the walkable environment plays a central role in the sustainable development of neighborhoods and is a key element to converge public health policies [40] at a national level and on-ground execution at a local level (Figure 2). 


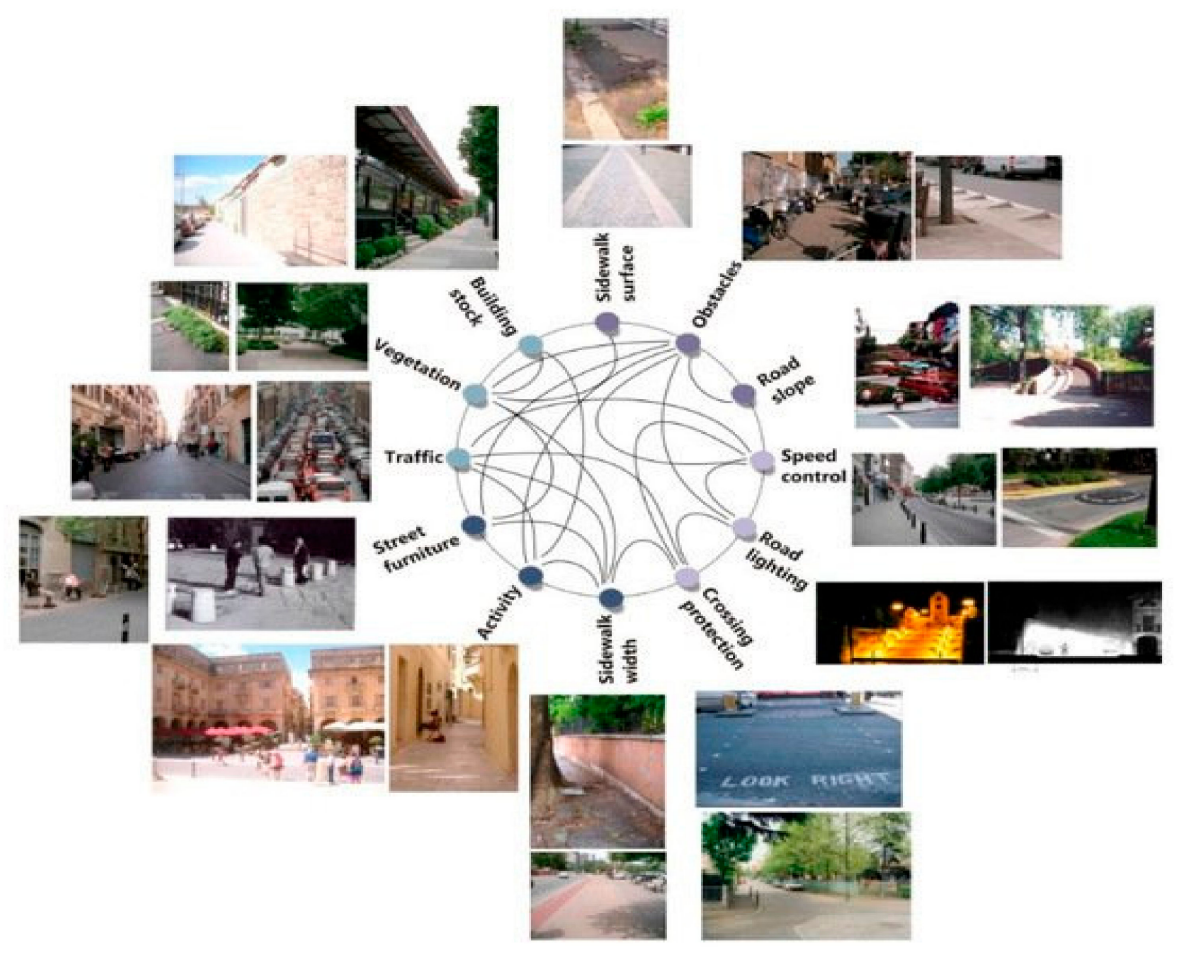

Figure 2. Interrelation among the different walking requirements [41].

\section{Theoretical Model}

We have designed a conceptual model based upon the perceived environmental attributes of a walkable neighborhood, which includes the following factors: Land Use Mix, Street Connectivity, Pedestrian Infrastructure, Aesthetics, Shading, Safety, and Perceived Residential Density. Subsequently, we assessed the influence of each one of the attributes on the functional walking behavior, using the software Smart PLS-SEM.

This conceptual model entails seventeen (17) construct indicator variables that are clustered into six categories, which are also known as exogenous latent variables. This model explains the relationships between manifest variables and their relative latent variables. The conceptual model showing the relationships between the manifest variables and exogenous latent variables is shown in Figure 3.

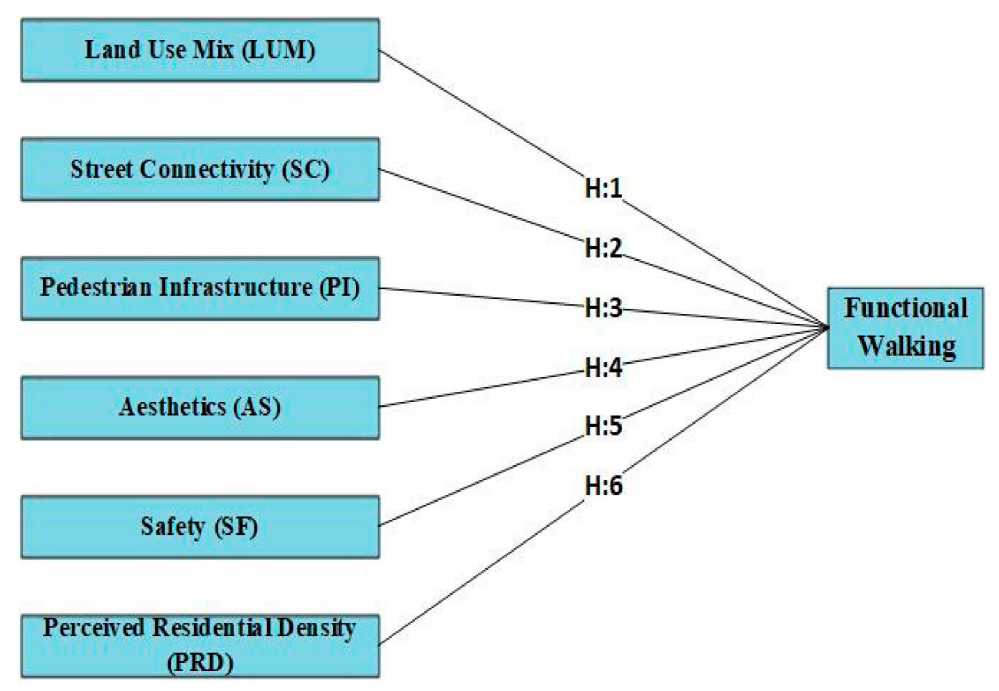

Figure 3. Theoretical Model of the Functional Walking Behavior. 


\subsection{H1: Land Use Mix $\rightarrow$ Functional Walking}

In the present study, Land Use Mix defines the diversity of uses of a certain area, while Destination Access (DA) is how easily they can be reached by walking. The most widely spread objective estimate of Land Use Mix (LUM) is mixed-use entropy, while DA is commonly measured by the gravity model of trip attraction [28]. Perceived diversity (LUM and DA) is assessed by the perceived distance and availability of services and recreational facilities. This variable in the IPEN project also displays a significant positive impact on walking.

\subsection{H2: Street Connectivity $\rightarrow$ Functional Walking}

Street Connectivity represents a movement network with diversity and multiple choices for reaching destinations. Smaller block sizes, higher intersection density, and low occurrence of dead ends are deciding environmental characteristics to create a movement network supportive of pedestrian activity. The results of IPEN showed a positive correlation between node (intersection) density and walking levels. Similarly, perceived connectivityoperationalized as many ways to get to destinations-was associated with higher levels of pedestrian activity. However, connectivity alone might not be able to guarantee higher walking levels.

\subsection{H3: Pedestrian Infrastructure $\rightarrow$ Functional Walking}

Planning features associated with Pedestrian Infrastructure, Safety, and Aesthetics are mostly covered by the third " $\mathrm{D}$ ", for "Density" [16]. Pedestrian Infrastructure is related to comfortably paved walkways, shading trees, streetlights, and so forth. Pedestrian Infrastructure (PI) is considered to have a positive impact on walking for transport (according to IPEN).

\subsection{H4: Aesthetics $\rightarrow$ Functional Walking}

An attractive neighborhood is more supportive of pedestrian activity. The existence of beautiful buildings and facades, greenery, beautiful sights, and so forth make an aesthetically appealing environment. Nevertheless, the results of the IPEN study show that Aesthetics has a positive but low impact on walking levels.

\subsection{H5: Safety $\rightarrow$ Functional Walking}

Both traffic safety and crime safety might hinder pedestrian activity. There are many traffic calming strategies to reduce driving speed and increase perceived safety, such as curbside parking, reducing curb radii, and reducing street profiles (road diets). Similarly, designing an environment where more social interaction happens, avoiding blank facades and "Big Box" development, induces a sense of safety. Within the IPEN study, the association between safety and walking was not conclusive.

\subsection{H6: Perceived Residential Density $\rightarrow$ Functional Walking}

Researchers like Newman et al. [14] have stressed that pedestrian or walking cities are dense, with over 100 people per ha. Regulating Residential Density is a key strategy to tackle suburbanization $[42,43]$. Besides the population occurrence, density can also be measured in the function of the built area (floor area ratio) or dwelling density. Hence, perceived density is usually associated with the prevalence of building types (fewer single-family houses, more condos). The results of the IPEN study in 2012 demonstrated a strong correlation between perceived density and walking transport ( $>150 \mathrm{~min} /$ week). Their relationship is defined by an ascending curve, stagnating towards high and very high-density levels.

\section{Materials and Methods}

\subsection{Research Framework}

A complete comprehensive framework is shown in Figure 4, by which one can easily follow the research pattern of this research. 


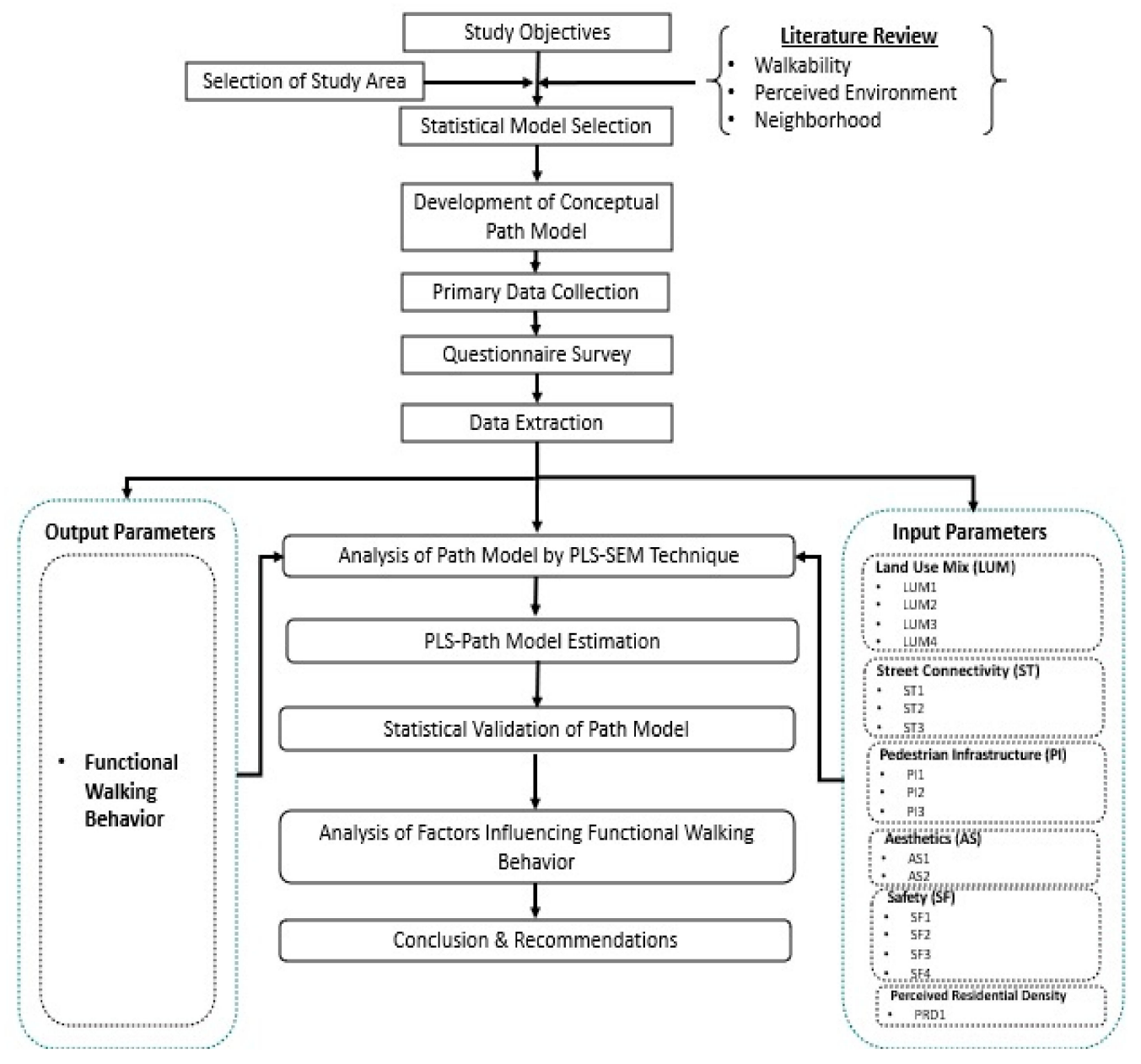

Figure 4. Framework of research.

\subsection{Study Area and Geography}

This research study adopted a quantitative research approach involving data collection through structured questionnaires, using an adapted version of the Neighborhood Environment Walkability Scale [44]. A survey was carried out amongst 11 different neighborhoods in Muscat, Oman, as shown in Figure 5. A total of 1150 questionnaires were distributed among randomly selected individuals within these 11 neighborhoods. The questionnaire survey was distributed during face-to-face interactions with residents of each neighborhood. They were told the purpose of the research study and questionnaires were given to the people willing to participate in the survey. As a result, 1113 questionnaires were considered complete, and 37 questionnaires were incomplete and considered inappropriate. The analysis used 1113 completed questionnaires, which were sufficient for the sample size requirements, as a rule of thumb, in PLS-SEM [45,46]. 


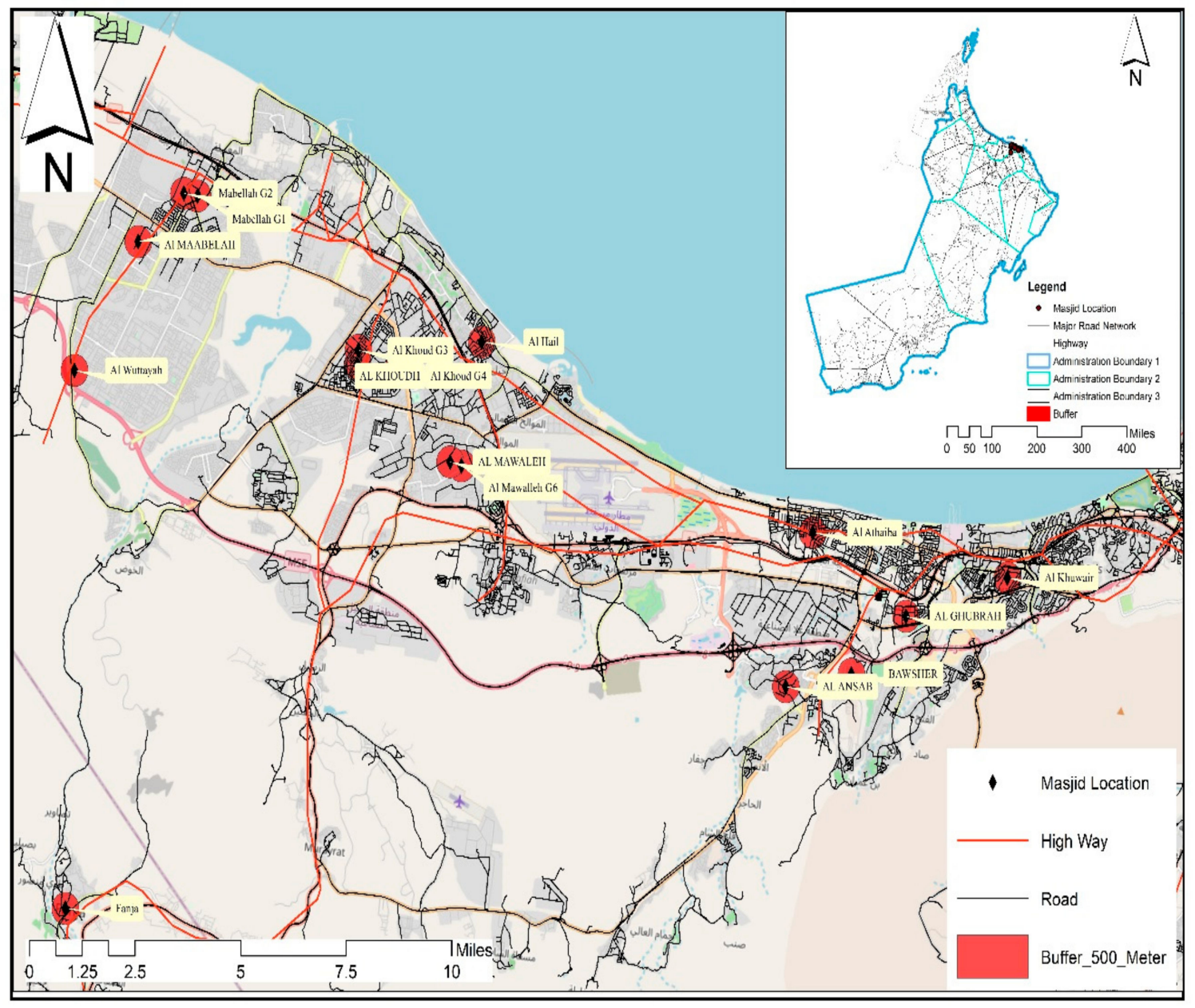

Figure 5. Study area of Muscat, Oman.

\subsection{Data Collection}

Measurements for the dimensions of the physical environment for walking (Land Use Mix, Street Connectivity, Pedestrian Infrastructure, Aesthetics, Shading, Safety, and Perceived Residential Density) were taken from the previous studies of the IPEN (International Physical Activity and the Environment Network) project. To develop a comprehensive set of measurement items, extensive literature was reviewed and we conducted focus group discussions involving local people. As a result, seventeen (17) items related to the six dimensions of the perceived walking environment were developed: Land Use Mix (4 items); Street Connectivity (3 items); Pedestrian Infrastructure (3 items); Aesthetics ( 2 items); Safety (4 items), and Perceived Residential Density. All of these items were reworked to fit the context of the study. A 4-point Likert scale ranging from 1 ("Strongly Disagree") to 4 ("Strongly Agree") was used to measure these items. The questionnaire was sent to the academic assessors for review; some structural and grammatical changes made the questionnaire statements easier to understand and gave them more credibility. The description of the manifest variables and their relative exogenous latent variables are presented in Table 1. 
Table 1. Perceived environmental attributes and descriptions.

\begin{tabular}{|c|c|c|}
\hline Group/Construct & Item & Description of Item \\
\hline \multirow[t]{4}{*}{ Land Use Mix (LUM) } & LUM1 & $\begin{array}{l}\text { The stores are within an easy walking distance of } \\
\text { my house. }\end{array}$ \\
\hline & LUM2 & $\begin{array}{l}\text { There are major barriers to walk in my local area that } \\
\text { make it hard to get from place to place (for example, } \\
\text { freeways, rivers, etc.). }\end{array}$ \\
\hline & LUM3 & $\begin{array}{l}\text { There are many places to go within an easy walking } \\
\text { distance of my home. }\end{array}$ \\
\hline & LUM4 & $\begin{array}{l}\text { It's easy to walk to a transit stop (bus, taxi) from } \\
\text { my home. }\end{array}$ \\
\hline \multirow[t]{3}{*}{ Street Connectivity (SC) } & SC1 & $\begin{array}{c}\text { Streets in my neighborhood do not have many } \\
\text { cul-de-sacs. }\end{array}$ \\
\hline & SC2 & $\begin{array}{c}\text { The distance between intersections in my } \\
\text { neighborhood is usually short ( } 90 \mathrm{~m} \text { or less; length of } \\
\text { a football field). }\end{array}$ \\
\hline & SC3 & $\begin{array}{l}\text { There are many alternative routes to get from place to } \\
\text { place in my neighborhood (I don't have to go the same } \\
\text { way every time). }\end{array}$ \\
\hline \multirow[t]{3}{*}{$\begin{array}{l}\text { Pedestrian Infrastructure } \\
\qquad(\mathrm{PI})\end{array}$} & PI1 & $\begin{array}{c}\text { There are sidewalks on most of the streets in } \\
\text { my neighborhood. }\end{array}$ \\
\hline & PI2 & $\begin{array}{c}\text { The walking paths are well shaded in } \\
\text { my neighborhood. }\end{array}$ \\
\hline & PI3 & There are trees along the streets in my neighborhood. \\
\hline \multirow[t]{2}{*}{ Aesthetics (AS) } & AS1 & $\begin{array}{l}\text { There is too much garbage near the paths that make it } \\
\text { unpleasant to walk in my neighborhood. }\end{array}$ \\
\hline & AS2 & $\begin{array}{l}\text { There are attractive natural sights and attractive } \\
\text { facades in my neighborhood. }\end{array}$ \\
\hline \multirow[t]{4}{*}{ Safety (SF) } & SF1 & $\begin{array}{l}\text { There is so much traffic along the streets that it makes } \\
\text { it unpleasant or difficult to walk in my neighborhood. }\end{array}$ \\
\hline & SF2 & $\begin{array}{c}\text { There are crosswalks and pedestrian signals to help } \\
\text { walkers cross the busy streets. }\end{array}$ \\
\hline & SF3 & My neighborhoods' streets are well lit at night. \\
\hline & SF4 & The speed of traffic on most streets is usually low. \\
\hline $\begin{array}{l}\text { Perceived Residential } \\
\text { Density (PRD) }\end{array}$ & PRD1 & $\begin{array}{l}\text { Typology of buildings in the immediate neighborhood } \\
\text { (i.e., single-family villas, twin villas, Arab style houses, } \\
\text { apartment buildings). }\end{array}$ \\
\hline
\end{tabular}

\subsection{Application of PLS-SEM Modelling Technique}

Here, a well-established structural equation modeling (SEM) approach was applied, which performs like a new second-generation multivariate data analysis method, helping in the analysis of complex relationships [47-50]. It has a comprehensive approach, known as "partial least square structural equation modeling" (PLS-SEM) techniques, using SmartPLS to provide a visualization approach to overview many variables and prioritize better options for variables, as shown in Figure 6. 


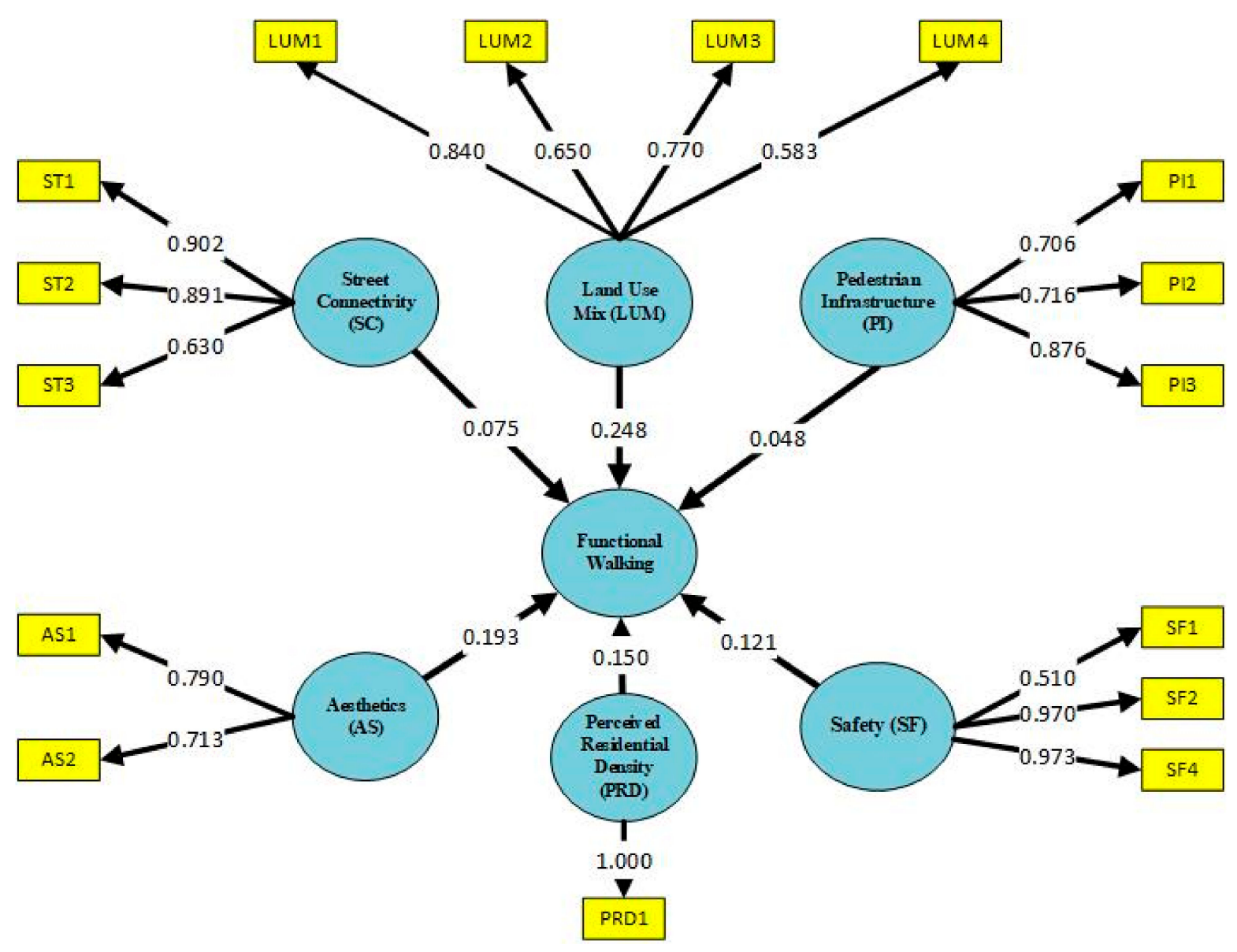

Figure 6. PLS-structural equation model formation.

\section{Analysis and Results}

Analysis of the data was carried out by using a Smart PLS simulation of the conceptual model to assess the strength of each latent variable/factor affecting the functional walking behavior. A two-step procedure was involved, which included (1) the assessment of the PLS model parameters by a separate method by resolving the wedges of the measurement model, and then (2) reckoning the parameter estimates of the structural model [51,52]. Overall, the structural equation model was corroborated by the value of the R-square. To ensure the strength of each factor was consistent and reliable, the conceptual model used in Smart PLS simulation needed to be evaluated. This process of evaluation involved four steps, as follows:

1. Convergent Validity and Individual Item Validity

2. Discriminant Validity

3. Structural Model Relationships

4. Overall Fitness of the Model

\subsection{Convergent Validity and Individual Item Validity}

The consistency and validity of the manifest variables were gauged through the measurement model. Initially, the measurement model was verified for convergent validity. This was evaluated through Composite Reliability (CR), Factor Loadings, and Average Variance Extracted (AVE). The cogency of the measurement model was assessed through convergent validity [53]. The values of the Composite Reliability (CR) portray the degree to which manifest variables indicate the constructs (as in Table 2) of the latent variables by the calculation of the standardized outer loadings of the specific construct indicators. 
Table 2. Individual item reliability and convergent validity.

\begin{tabular}{|c|c|c|c|c|c|c|c|}
\hline \multirow{2}{*}{ Constructs } & \multicolumn{4}{|c|}{ First Iteration } & \multicolumn{3}{|c|}{ Final Iteration } \\
\hline & Items & Loading & AVE & CR & Loading & AVE & CR \\
\hline \multirow{4}{*}{ Land Use Mix (LUM) } & LUM1 & 0.840 & \multirow{4}{*}{0.515} & \multirow{4}{*}{0.722} & 0.840 & \multirow{4}{*}{0.515} & \multirow{4}{*}{0.722} \\
\hline & LUM2 & 0.650 & & & 0.650 & & \\
\hline & LUM3 & 0.770 & & & 0.770 & & \\
\hline & LUM4 & 0.583 & & & 0.583 & & \\
\hline \multirow{3}{*}{ Street Connectivity (SC) } & SC1 & 0.902 & \multirow{3}{*}{0.668} & \multirow{3}{*}{0.855} & 0.902 & \multirow{3}{*}{0.668} & \multirow{3}{*}{0.855} \\
\hline & SC2 & 0.891 & & & 0.891 & & \\
\hline & SC3 & 0.630 & & & 0.630 & & \\
\hline \multirow{3}{*}{ Pedestrian Infrastructure (PI) } & PI1 & 0.706 & \multirow{3}{*}{0.592} & \multirow{3}{*}{0.812} & 0.706 & \multirow{3}{*}{0.592} & \multirow{3}{*}{0.812} \\
\hline & PI2 & 0.716 & & & 0.716 & & \\
\hline & PI3 & 0.876 & & & 0.876 & & \\
\hline \multirow{2}{*}{ Aesthetics (AS) } & AS1 & 0.790 & \multirow{2}{*}{0.566} & \multirow{2}{*}{0.722} & 0.790 & \multirow{2}{*}{0.566} & \multirow{2}{*}{0.722} \\
\hline & AS2 & 0.713 & & & 0.713 & & \\
\hline \multirow{4}{*}{ Safety (SF) } & SF1 & 0.451 & \multirow{4}{*}{0.528} & \multirow{4}{*}{0.769} & 0.510 & \multirow{4}{*}{0.70} & \multirow{4}{*}{0.865} \\
\hline & SF2 & 0.105 & & & Omitted & & \\
\hline & SF3 & 0.975 & & & 0.975 & & \\
\hline & SF4 & 0.973 & & & 0.973 & & \\
\hline Perceived Residential Density (PRD) & PRD1 & 1.0 & 1.0 & 1.0 & 1.0 & 1.0 & 1.0 \\
\hline
\end{tabular}

Manifest variables that have a value of the outer loadings of 0.7 or higher are considered extremely suitable [52-54]. The loading value of 0.5 for the specific manifest variable suggests that the outer loading value of 0.4 should be acceptable. If the exclusion of these specific construct indicators surges the value of Composite Reliability (CR), then it is rational to discard specific indicators; otherwise, these indicators should be maintained in the analysis. The cut-off mark for the values of the outer loadings of construct indicators was taken as 0.5 in this research. An iterative procedure was espoused for the exclusion of the construct indicators. Measurement model consistency was also evaluated through the construct reliability, which was assessed by the values of Composite Reliability (CR) and Cronbach's alpha. Ref. [49] recommended that the value of Composite Reliability (CR) is suitable if it is above 0.7 and they further argued that the construal of Cronbach's alpha and Composite Reliability (CR) is similar. However, the better measure by which to assess the internal consistency of the measurement model is Composite Reliability (CR), as it engages the standardized loadings of the construct indicators [46,55]. As a next step, the discriminant validity of the measurement model was assessed, which refers to the degree to which measures are not a replication of other indicator variables; this was analyzed by the indication of low correlations between the measures of other constructs and the measures of interest. A discriminant validity test was performed to analyze that the construct indicator in any construct is related to the chosen construct where its cross-loading value in a specific construct should be higher than any other construct [56].

The AVE (Average Variance Extracted) test was performed to assess the Convergent Validity of the model [55]. The amount of variance extracted by the latent variable from its relative indicator variable was analyzed by the value of the AVE. Refs. [46,57] recommended that latent variables must extract a minimum amount of $50 \%$ of variance from their relative construct indicator This means that the AVE value of the latent variable should be greater than 0.5. The measurement model was evaluated based upon the above-mentioned criteria and an iterative simulation process was adopted to discard the weak manifest variables. In the first iteration of Table 1, six constructs (Land Use Mix, Pedestrian Infrastructure, Street Connectivity, Aesthetics, Safety, and Perceived Residential Density) have parametric values above the cut-off mark, while one manifest variable within the construct of "Safety" proved to be very weak. In the following iteration, this weak manifest variable was discarded and better AVE and CR values were achieved. Once the whole iteration process was completed, 
the final measurement model was evaluated for discriminant validity, which was assessed by the values of the cross-loadings. Cross loading values are shown in Table 3.

Table 3. Analysis of cross-loadings of factors.

\begin{tabular}{ccccccc}
\hline & LUM & ST & PI & AS & SF & PRD \\
\hline LUM1 & 0.840 & 0.393 & 0.214 & 0.302 & 0.218 & 0.289 \\
LUM2 & 0.650 & 0.125 & 0.142 & 0.085 & 0.391 & 0.057 \\
LUM3 & 0.770 & 0.345 & 0.321 & 0.396 & 0.174 & 0.257 \\
LUM4 & 0.583 & 0.212 & 0.161 & 0.075 & 0.149 & 0.116 \\
ST1 & 0.284 & 0.902 & 0.173 & 0.328 & 0.173 & 0.290 \\
ST2 & 0.198 & 0.891 & 0.127 & 0.297 & 0.155 & 0.263 \\
ST3 & 0.448 & 0.630 & 0.069 & 0.247 & 0.233 & 0.245 \\
PI1 & 0.240 & 0.079 & 0.706 & 0.328 & -0.080 & 0.192 \\
PI2 & 0.149 & 0.084 & 0.716 & 0.193 & -0.009 & 0.125 \\
PI3 & 0.271 & 0.165 & 0.786 & 0.354 & -0.023 & 0.247 \\
AS1 & 0.258 & 0.285 & 0.415 & 0.790 & -0.050 & 0.353 \\
AS2 & 0.217 & 0.256 & 0.155 & 0.713 & 0.097 & 0.210 \\
SF1 & 0.066 & 0.205 & 0.011 & 0.012 & 0.451 & 0.189 \\
SF3 & 0.016 & 0.309 & -0.043 & 0.077 & 0.975 & 0.205 \\
SF4 & 0.004 & 0.310 & 0.061 & 0.076 & 0.973 & 0.201 \\
PRD1 & 0.260 & 0.329 & 0.256 & 0.380 & 0.073 & 1.00 \\
\hline
\end{tabular}

\subsection{Discriminant Validity}

After the assessment of the convergent validity and individual item reliability of the measurement model, the discriminant validity of the latent variables/constructs was evaluated. Discriminant validity specifies the extent to which a specific construct is different from the other constructs [58]. The discriminant validity of the measurement model can be evaluated by the values of the cross-loadings.

This follows the rule that "items should have a higher correlation with the latent variable that they are supposed to measure than with any other latent variable in the model [56]". The evaluation of discriminant validity is shown in Table 3 . The results indicate that the values of the cross-loadings of construct indicators are higher on their relative constructs/latent variables as compared to the other constructs/latent variables.

These higher values of cross-loadings verify that the manifest variables in each construct represent the assigned construct, attesting to the discriminant validity of the measurement model.

\subsection{Structural Model Relationships}

Structural Model relationships were analyzed to determine the significance of individual paths and the explanatory power of the model. Ref. [49] recommended looking at the values of $\beta$ (beta) and the R-square to analyze the strength of the Structural Model. However, it was necessary to test the $\beta$ value for its significance level through a $t$-test. In Smart PLS, this test was accomplished by the execution of the non-parametric bootstrapping technique [59]. The bootstrapping technique calculates the $t$-values by generating a prespecified number of samples. Ref. [53] recommended that the acceptable $t$-values for a two-tailed $t$-test are 1.65 ( significance level $=10 \%), 1.96$ (significance level $=5 \%$ ) and 2.58 (significance level $=1 \%$ ). In this research study, bootstrapping formed 5000 samples; then, these samples were used to calculate $t$-values, which are presented in Table 4 . Table 4 represents the values of the path coefficients of all the latent variables and their corresponding $t$-values.

The structural model indicates the relationships between the endogenous and exogenous constructs by assessing them through the values of path coefficients (beta) and coefficient of determination (R-square) [53]. The value of the path coefficient (beta) refers to the strength of an effect of an exogenous latent variable on the endogenous latent variable and the value of the R-square refers to the degree of variance that could be explained by the structural model [60-62]. A suitable model fit requires the value of the R-square to 
be greater than 0.26 [63]. Since the value of the R-square of our developed model is 0.29 , which is above the recommended value, means that the developed model (as shown in Figure 7) is considered to possess a substantial degree of explained variance of "Functional Walk" by the perceived environmental factors. In the next step, the path coefficients $(\beta)$ of all the latent variables were assessed and compared. All the path coefficients $(\beta)$ attained $t$-values greater than the cut-off mark for a significance level of $1 \%$, except the latent variable "Pedestrian Infrastructure". This implies that all the path coefficients in the estimated model have a strong impact on the "Functional Walking" except "Pedestrian Infrastructure". The highest $\beta$ value (0.248) was attained for "Land Use Mix" and it is the most significant factor influencing "Functional Walking" for the residents of Muscat.

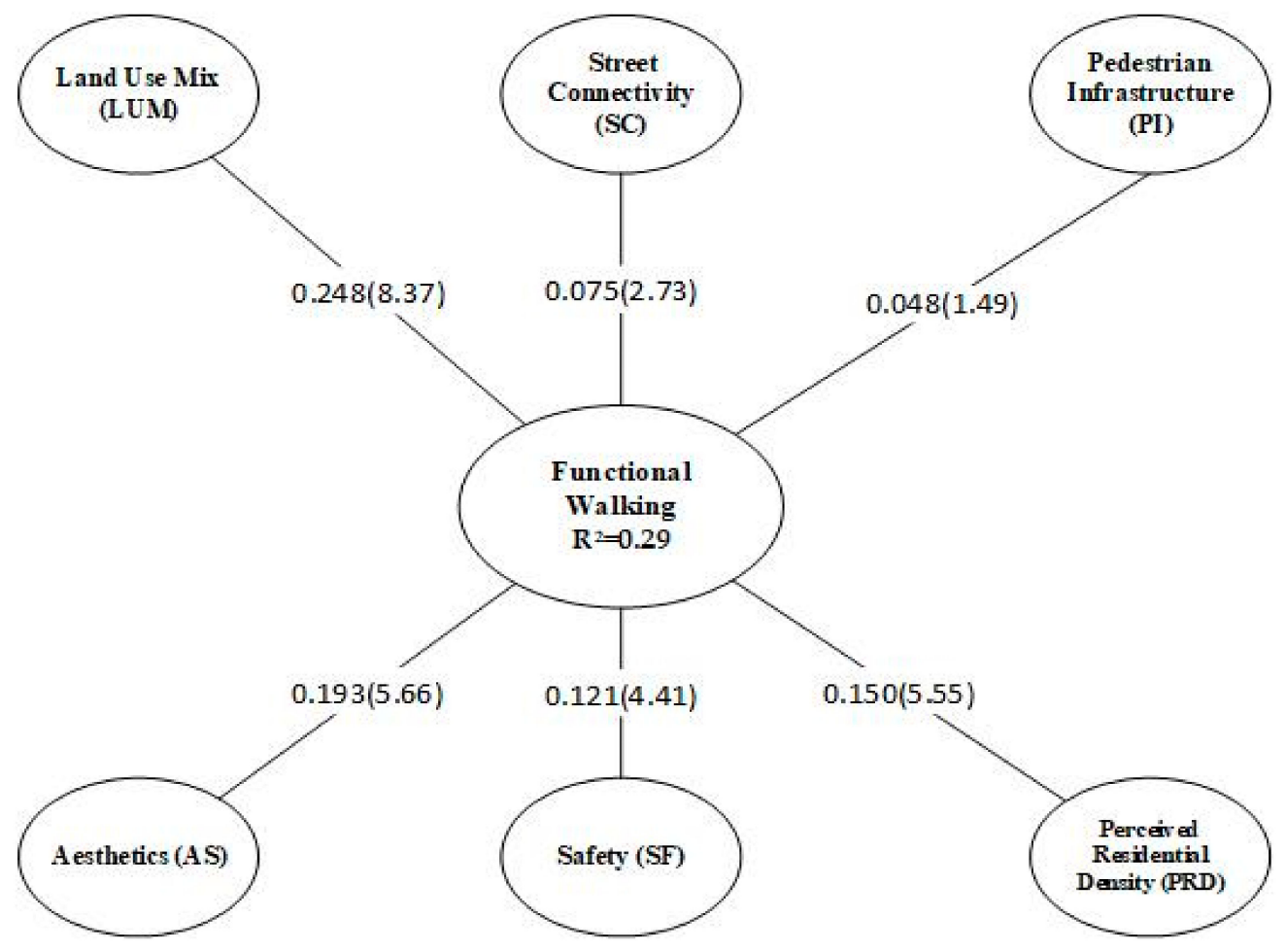

Figure 7. Structural model relationships.

Table 4. Structural model significance.

\begin{tabular}{cccc}
\hline Abbreviation & Constructs & Path Coefficient $(\boldsymbol{\beta})$ & $\boldsymbol{t}$-Value \\
\hline LUM & Land Use Mix & 0.248 & $8.37^{*}$ \\
ST & Street Connectivity & 0.075 & $2.73^{*}$ \\
PI & Pedestrian Infrastructure & 0.048 & 1.49 \\
AS & Aesthetics & 0.193 & $5.66^{*}$ \\
SF & Safety & 0.121 & $4.41^{*}$ \\
PRD & Perceived Residential Density & 0.150 & $5.55^{*}$ \\
\hline
\end{tabular}

Note: * Significant $(p<0.01)$.

\subsection{Overall Model Fitness Analysis}

To assess the global validity and explain the power of the structural equation model, the overall fitness of the model was tested through the Goodness of Fit (GoF) index. GoF is defined as the geometric mean of the average $R^{2}$ of all endogenous latent variables/constructs and average commonality $[60,64]$. The overall intent of the evaluation GoF index was to examine the PLS model performance at both structural and measurement model levels, with an emphasis on the prediction power of the model [64]. Studies [55,63,65] provided the guidelines and the GoF cut-off values for the global validation of the PLS models and 
suggested the value of 0.50 as the cut-off value for communality and diverse effect sizes of $R^{2}$. The GoF index of the PLS model and its criteria are explained in Table 5.

Table 5. GoF index and its criteria [60].

\begin{tabular}{cc}
\hline GoF & GoF Criteria \\
\hline GoF $=\sqrt{\overline{\text { Communality }} \times \overline{R^{2}}}$ & Communality $=0.5[55]$ \\
$R^{2}$ effect: & Small $=0.02$, Medium $=0.13$, Large $=0.26$ \\
Range of $\mathrm{GoF}$ values: & Thus, \\
GoF $=(0<\mathrm{GoF}<1)$ & GoFmedium $=\sqrt{0.5 X 0.02}=0.10$ \\
& GoFmedium $=\sqrt{0.5 X 0.13}=0.25$ \\
& GoFlarge $=\sqrt{0.5 X 0.26}=0.36$ \\
\hline
\end{tabular}

From Table 3, it is established that the GoFlarge (0.36), GoFmedium (0.25), and GoFsmall (0.10) are the cut-off values of the GoF index. The overall fitness of the PLS model was calculated using the following Equation (1):

$$
\mathrm{GoF}=\sqrt{\overline{A V E} \times \overline{R^{2}}}
$$

In this research study, the value of the $R^{2}$ was 0.29 , while $\overline{A V E}$ was calculated as the average of all AVE values, as explained in Table 1. By using the AVE values of all the exogenous latent variables, the average came out to be 0.673 .

$$
\begin{gathered}
\mathrm{GoF}=\sqrt{0.673 \times 0.29} \\
\mathrm{GoF}=0.44
\end{gathered}
$$

Since the GoF value calculated in Equation (3) was greater than the cut-off value of 0.36 , which is required for the substantial model, the GoF value of 0.44 endorses that the model developed for this research study is substantial in explaining the relation between the perceived environmental attributes and the functional walking behavior of residents. The parameters used in the model are reliable and consistent and backed up by the IPEN project.

\section{Discussion}

Our research findings point to the important differences in the perceived environmental attributes that influence the functional walking behavior of individuals. Although, it is evident from the existing literature that previous researchers have uncovered physical environmental attributes that are significantly correlated with the behavior of physical activity [66-69]. However, the relative importance of the perceived environmental attributes had not been investigated. Therefore, we attempted the well-established structural equation modeling (SEM) approach to explore this relative importance. Our results are somehow consistent with the findings of the prior research studies [66,70-72]; perceived attributes that are related to the Land Use Mix, Safety, and Aesthetics have proved to be most important for walking. Land Use Mix is not surprisingly the latent variable with the highest load on walking behavior [73]. Despite the dominant mono-functional character of the new residential neighborhoods in Muscat, the areas where we carried out the surveys (delimited by a $400 \mathrm{~m}$ radius around the mosque) concentrated a small cluster of commerce and services. Previous research [74] revealed that walking to prayers is the most common active mobility activity performed by residents of Muscat. Additionally, it is prescribed by law to allocate a small number of shops and services such as a tailor, grocery, coffee shop, and so forth to cover the daily needs of residents and to help to sustain the mosque economically. That small mixed-use core in each neighborhood varies substantially, according to the level of development of the surroundings. Consequently, despite the lacking diversity of functions (considering objective parameters, such as entropy, job-dwelling ratios, etc.) 
necessary to guarantee a higher level of walking for transport, residents are still exposed to at least a certain degree of land use mix in these core areas.

Conversely, the perception of the subjects on the pedestrian infrastructure does not seem to influence their walking behavior substantially. The latent variable has the lowest load, which was an unexpected result. Nevertheless, a closer look at the environmental characteristics of the studied locations gives us some insight into the results. Again, walking and physical activity levels are extremely low in any of the studied areas. Due to a rapid expansive growth ratio in Muscat since the 1970s, authorities were not able to provide basic infrastructure to the ever-expanding sprawling city. Consequently, open spaces usually remain deprived of any basic attributes, such as walkways, street furniture, and greenery. If any, the only infrastructural element present is an asphalted road in the middle. The space between the road and the boundary walls surrounding the private lots (usually singledetached houses) is commonly regarded as an "unofficial" extension of the private domains and invariably treated as additional parking space. Residents call them "interlocks" because it is the most common construction material used to pave them. Whenever present, the paving of the interlocks occurs as an individual initiative without any dialogue with the direct neighbors, resulting in uneven levels, inconsistent design obstructed by cars, or other barriers, such as bushes or fences. In the residential neighborhoods of Muscat, the pedestrian movements happen in an improvised challenging environment without trees to cast shade, over an uncomfortable ground to walk, and often in the middle of the road. In addition, if Omanis are not used to use a pedestrian infrastructure to walk as they are often absent in their neighborhoods, how could they perceive them accurately? Nonetheless, it does not necessarily mean that the existence of a pedestrian infrastructure would not contribute to enhancing active transport. Reflecting on the structure of the questionnaire and comparing it with the environment subjects are exposed to, it seems challenging to fit an extremely changeable environment into one single judgment.

Aesthetic, traffic safety and residential densities are stable environmental elements possible to address, even detached from pedestrian activity [75-77]. One can easily experience beautiful sights or different building typologies passing by while driving or parking the cars. Similarly, a general impression of whether some apartment towers are sticking out of the generally flattened landscape composed predominantly of single-family houses or twin villas does not require a walk around, as the higher rise buildings are usually built closer to arterial roads. Street connectivity is operationalized as node density and intersection connectivity. Those measurements are usually perceived by the size of the blocks and the permeability of the streets network. Similarly, to pedestrian infrastructure, connectivity is another environmental attribute strongly related to walking behavior since its perception does not overlap with drivers' experiences. This explains why Street Connectivity is a construct with a relatively low load.

\section{Conclusions}

The study assessed the impact of perceived environmental elements in Oman on walking behavior. Although a number of aforementioned studies have investigated the correlation between individual attributes and physical activity, our study has attempted to investigate the relative importance of perceived environmental attributes, more specifically in the context of a developing country, and concludes that policies for the increase of density levels allied with mixed-use development in strategic areas are likely to have the highest potential to activate the communities in sprawling areas. We have also concluded that when walking studies are applied in environments with extremely low walkable features and car-oriented communities, the estimates are likely to be dominated by the drivers' perspectives rather than the pedestrians' perspectives, reducing the accuracy of some constructs. In such circumstances, the results of parameters, such as Street Connectivity and Pedestrian Infrastructure, are likely to be skewed. Our methodology to study the relative importance of perceived environmental attributes on walking behavior may act as a guide for decision-makers and urban planners who wish to implement and develop a 
proper walking environment in the context of developing countries. There may be some constructs/features of walking environments that are perceived as less important because the survey participants are not used to these environments. Additionally, to the survey results, other methods, such as objective mapping and qualitative research, are required to validate the latter assumption.

\section{Limitations of the Study}

The theory of walkable cities has guided several urban development policies worldwide. However, it is more emphatically used in countries with recent peaks of development, such as the United States [42] and Australia [43,78]. One central goal of those policies is to leverage poly-centric development aiming to reverse the negative effects of expansionism and suburbanization. Studies adapting methodologies for developing countries with extreme growth ratios are proliferating and substantially contributing to expanding the scope of the field [6,79-83]. Nevertheless, it is still unclear what the impacts are of rapid growth and the absence of a well-established infrastructure on the prediction's accuracy over the methodology in question. Consequently, this study tested two concurring hypotheses:

1. Prevailing methodologies to assess the associations between environmental attributes and perceived walkability are universal. Walkability tools, in their current state, are directly applicable.

2. Rapid urbanization associated with different levels of development of urban infrastructure substantially impacts the perception of walkability. Prevailing walkability tools need adjustments.

In this study, we focused on the perceived environmental attributes and their impacts on walking behavior, especially in neighborhoods where the infrastructure is not well established.

Author Contributions: Conceptualization-G.d.S., analyses-A.A., A.A.B., Lit Review-P.P., writing, data collection, writing, and review-G.d.S., A.A., S.A.R.S. All authors have read and agreed to the published version of the manuscript.

Funding: This research was funded by the GUTech internal Seed Grant SGN-18/ 19-003.

Institutional Review Board Statement: Not Applicable.

Informed Consent Statement: Not Applicable.

Data Availability Statement: Data will be available on suitable demand.

Acknowledgments: We appreciate the support of Muscat Municipality, especially of the head of the approval sector Hilal Al Busaidi for his engagement and support for the WOW project. Moreover, special gratitude to Felix Heusch, Marianne Sigl, and Klaudia Dudyik for helping to develop the WOW Project.

Conflicts of Interest: The authors declare no conflict of interest.

\section{References}

1. Duany, A.; Plater-Zyberk, E.; Speck, J. Suburban Nation: The Rise of Sprawl and the Decline of the American Dream; Macmillan: New York, NY, USA, 2001.

2. Putnam, R.D. Bowling Alone: The Collapse and Revival of American Community; Simon and Schuster: New York, NY, USA, 2000.

3. Lund, H. Pedestrian Environments and Sense of Community. J. Plan. Educ. Res. 2002, 21, 301-312. [CrossRef]

4. Lund, H. Testing the Claims of New Urbanism: Local Access, Pedestrian Travel, and Neighboring Behaviors. J. Am. Plan. Assoc. 2003, 69, 414-429. [CrossRef]

5. Cerin, E.; Saelens, B.E.; Sallis, J.F.; Frank, L.D. Neighborhood Environment Walkability Scale: Validity and development of a short form. Med. Sci. Sports Exerc. 2006, 38, 1682. [CrossRef]

6. Oyeyemi, A.L.; Sallis, J.F.; Oyeyemi, A.Y.; Amin, M.M.; De Bourdeaudhuij, I.; Deforche, B. Adaptation, Test-Retest Reliability, and Construct Validity of the Physical Activity Neighborhood Environment Scale in Nigeria (PANES-N). J. Phys. Act. Health 2013, 10, 1079-1090. [CrossRef] [PubMed]

7. Frank, L.D.; Schmid, T.L.; Sallis, J.F.; Chapman, J.; Saelens, B.E. Linking objectively measured physical activity with objectively measured urban form: Findings from SMARTRAQ. Am. J. Prev. Med. 2005, 28, 117-125. [CrossRef] [PubMed] 
8. Leslie, E.; Coffee, N.; Frank, L.; Owen, N.; Bauman, A.; Hugo, G. Walkability of local communities: Using geographic information systems to objectively assess relevant environmental attributes. Health Place 2007, 13, 111-122. [CrossRef]

9. Gebel, K.; Bauman, A.; Sugiyama, T.; Owen, N. Mismatch between perceived and objectively assessed neighborhood walkability attributes: Prospective relationships with walking and weight gain. Health Place 2011, 17, 519-524. [CrossRef]

10. Loh, V.H.; Veitch, J.; Salmon, J.; Cerin, E.; Mavoa, S.; Villanueva, K.; Timperio, A. Environmental Mismatch: Do Associations between the Built Environment and Physical Activity among Youth Depend on Concordance with Perceptions? Int. J. Environ. Res. Public Health 2020, 17, 1309. [CrossRef]

11. Fan, P.; Wan, G.; Xu, L.; Park, H.; Xie, Y.; Liu, Y.; Yue, W.; Chen, J. Walkability in urban landscapes: A comparative study of four large cities in China. Landsc. Ecol. 2017, 33, 323-340. [CrossRef]

12. Barnett, G. Liveable Neighbourhoods-A Western Australian Government Sustainable Cities Initiative; Western Australian Planning Commission: Perth, Australia, 2000; p. 88.

13. Cheshmehzangi, A.; Dawodu, A. Sustainable Urban Development in the Age of Climate Change: People: The Cure or Curse; Springer: Berlin/Heidelberg, Germany, 2018.

14. Newman, P.; Kosonen, L.; Kenworthy, J. Theory of urban fabrics: Planning the walking, transit/public transport and automobile/motor car cities for reduced car dependency. Town Plan. Rev. 2016, 87, 429-458. [CrossRef]

15. Van Der Ryn, S.; Calthorpe, P. Sustainable Communities-A New Design Synthesis for Cities, Suburbs, and Towns; Sierra Club: San Francisco, CA, USA, 1986; Volume 6.

16. Ewing, R.; Cervero, R. Travel and the Built Environment: A Synthesis. Transp. Res. Rec. J. Transp. Res. Board 2001, 1780, 87-114. [CrossRef]

17. Keall, M.D.; Shaw, C.; Chapman, R.; Howden-Chapman, P. Reductions in carbon dioxide emissions from an intervention to promote cycling and walking: A case study from New Zealand. Transp. Res. Part D Transp. Environ. 2018, 65, 687-696. [CrossRef]

18. Molina-Garcí, A.Q.J.; Adams, M.A.; Conway, T.L.; Sallis, J.F. Neighborhood Built Environment and Socio-Economic Status in Relation to Multiple Health Outcomes in Adolescents. Available online: https:/ / www.sciencedirect.com/science/article/abs/ pii/S0091743517303122 (accessed on 1 January 2021).

19. Arvidsson, D.; Naomi, K.; Henrik, O.; Kristina, S. Physical activity and concordance between objective and perceived walkability. Med. Sci. Sports Exerc. 2012, 44, 280-287. [CrossRef] [PubMed]

20. Hinckson, E.; Cerin, E.; Mavoa, S.; Smith, M.; Badland, H.; Stewart, T.; Duncan, S.; Schofield, G. Associations of the perceived and objective neighborhood environment with physical activity and sedentary time in New Zealand adolescents. Int. J. Behav. Nutr. Phys. Act. 2017, 14, 145. [CrossRef]

21. Rogers, S.H.; Gardner, K.H.; Carlson, C.H. Social Capital and Walkability as Social Aspects of Sustainability. Sustain. 2013, 5, 3473-3483. [CrossRef]

22. Pivo, G.; Fisher, J.D. The Walkability Premium in Commercial Real Estate Investments. Real Estate Econ. 2011, 39, 185-219. [CrossRef]

23. Speck, J. Walkable City Rules: 101 Steps to Making Better Places; Island Press: Washington, DC, USA, 2018.

24. Jacobs, J. The Death and Life of Great American Cities; Random House: New York, NY, USA, 1961.

25. Chang, L.-Y.; Chu, H.-C.; Lin, D.-J.; Lui, P. Analysis of Freeway Accident Frequency using Multivariate Adaptive Regression Splines. Procedia Eng. 2012, 45, 824-829. [CrossRef]

26. Trudeau, D. A typology of New Urbanism neighborhoods. J. Urban. Int. Res. Placemaking Urban Sustain. 2013, 6, 113-138. [CrossRef]

27. Rodríguez, D.A.; Khattak, A.J.; Evenson, K.R. Can New Urbanism Encourage Physical Activity?: Comparing a New Urbanist Neighborhood with Conventional Suburbs. J. Am. Plan. Assoc. 2006, 72, 43-54. [CrossRef]

28. Ewing, R.; Cervero, R. Travel and the built environment: A meta-analysis. J. Am. Plan. Assoc. 2010, 76, 265-294. [CrossRef]

29. WHO. WHO Premature NCD Deaths. Available online: https://www.who.int/gho/ncd/mortality_morbidity/ncd_premature_ text/en/ (accessed on 5 January 2021).

30. Mabry, R. Urbanisation and Physical Activity in the GCC: A Case Study of Oman. Available online: https://www.semanticscholar org/paper/Urbanisation-and-physical-activity-in-the-GCC\%3A-a-of-Mabry/4057d708a1cf6b07ccc1945b30b26d6779e56159 (accessed on 1 January 2021).

31. Mabry, R.M.; Koohsari, M.J.; Bull, F.; Owen, N. A systematic review of physical activity and sedentary behaviour research in the oil-producing countries of the Arabian Peninsula. BMC Public Health 2016, 16, 1-22. [CrossRef]

32. Mabry, R.M.; Morsi, M.; Owen, N. Descriptive Epidemiology of Sitting Time in Omani Men and Women: A Known Risk Factor for Non-Communicable Diseases. Oman Med. J. 2017, 32, 233-239. [CrossRef]

33. Sultanate of Oman Ministry of Health. Health Vision 2050 Sultanate of Oman. Available online: https://www.moh.gov.om/ documents /16506/119833/Health+Vision+2050/7b6f40f3-8f93-4397-9fde-34e04026b829 (accessed on 1 January 2021).

34. Bourdeaudhuij, I.D.; Van Dyck, D.; Salvo, D.; Davey, R.; Reis, R.S.; Schofield, G.; Sarmiento, O.L.; Mitas, J.; Christiansen, L.B.; MacFarlane, D. International study of perceived neighbourhood environmental attributes and Body Mass Index: IPEN Adult study in 12 countries. Int. J. Behav. Nutr. Phys. Act. 2015, 12, 1-10. [CrossRef] [PubMed]

35. Van Dyck, D.; Cerin, E.; De Bourdeaudhuij, I.; Hinckson, E.; Reis, R.S.; Davey, R.; Sarmiento, O.L.; Mitas, J.; Troelsen, J.; Macfarlane, D.; et al. International study of objectively measured physical activity and sedentary time with body mass index and obesity: IPEN adult study. Int. J. Obes. 2015, 39, 199-207. [CrossRef] 
36. Van Dyck, D.; Cardon, G.; Deforche, B.; Owen, N.; Sallis, J.F.; De Bourdeaudhuij, I. Neighborhood Walkability and Sedentary Time in Belgian Adults. Am. J. Prev. Med. 2010, 39, 25-32. [CrossRef] [PubMed]

37. Kerr, J.; Sallis, J.F.; Owen, N.; De Bourdeaudhuij, I.; Cerin, E.; Sugiyama, T.; Reis, R.; Sarmiento, O.; Frömel, K.; Mitás, J.; et al. Advancing Science and Policy Through a Coordinated International Study of Physical Activity and Built Environments: IPEN Adult Methods. J. Phys. Act. Health 2013, 10, 581-601. [CrossRef]

38. Kerr, J.; Emond, J.A.; Badland, H.; Reis, R.; Sarmiento, O.L.; Carlson, J.; Sallis, J.F.; Cerin, E.; Cain, K.L.; Conway, T.; et al. Perceived Neighborhood Environmental Attributes Associated with Walking and Cycling for Transport among Adult Residents of 17 Cities in 12 Countries: The IPEN Study. Environ. Health Perspect. 2016, 124, 290-298. [CrossRef]

39. Hagstromer, M.S.M.; Hagströmer, M.; Oja, P.; Sjöström, M. The International Physical Activity Questionnaire (IPAQ): A study of concurrent and construct validity. Public Health Nutr. 2006, 9, 755-762. [CrossRef] [PubMed]

40. Giles-Corti, B.; Vernez-Moudon, A.; Reis, R.; Turrell, G.; Dannenberg, A.L.; Badland, H.; Foster, S.; Lowe, M.; Sallis, J.F.; Stevenson, M.; et al. City planning and population health: A global challenge. Lancet 2016, 388, 2912-2924. [CrossRef]

41. Appolloni, L.; Corazza, M.V.; D’Alessandro, D. The Pleasure of Walking: An Innovative Methodology to Assess Appropriate Walkable Performance in Urban Areas to Support Transport Planning. Sustainability 2019, 11, 3467. [CrossRef]

42. Park, K.; Ewing, R.; Sabouri, S.; Choi, D.-A.; Hamidi, S.; Tian, G. Guidelines for a Polycentric Region to Reduce Vehicle Use and Increase Walking and Transit Use. J. Am. Plan. Assoc. 2020, 86, 236-249. [CrossRef]

43. WAPC. Liveable Neighbourhoods: A Western Government Sustainable Cities Initiative 2009; Western Australian Planning Commission: Perth, Australia, 2009.

44. De Siqueira, G.L.; Petrovic, A.A.B.O.; Pasha, P. Where Omanis Walk? A Comparison between the Perception and the Morphology of the Built Environment in different Neighborhoods of Muscat. In Proceedings of the AMPS Proceedings Series 13. Constructing an Urban Future, Abu Dhabi University, Abu Dhabi, United Arab Emirates, 18-19 March 2018; pp. 64-72.

45. Westland, J.C. Lower bounds on sample size in structural equation modeling. Electron. Commer. Res. Appl. 2010, 9, 476-487. [CrossRef]

46. Hair, J.F.; Ringle, C.M.; Sarstedt, M. PLS-SEM: Indeed a Silver Bullet. J. Mark. Theory Pr. 2011, 19, 139-152. [CrossRef]

47. Henseler, J.; Chin, W.W. A Comparison of Approaches for the Analysis of Interaction Effects Between Latent Variables Using Partial Least Squares Path Modeling. Struct. Equ. Model. A Multidiscip. J. 2010, 17, 82-109. [CrossRef]

48. Haenlein, M.; Kaplan, A.M. A beginner's guide to partial least squares analysis. Underst. Stat. 2004, 3, 283-297. [CrossRef]

49. Hair, J.F., Jr.; Sarstedt, M.; Hopkins, L.; Kuppelwieser, V.G. Partial least squares structural equation modeling (PLS-SEM). Eur. Bus. Rev. 2014, 26, 106-121. [CrossRef]

50. Garson, D. Partial Least Squares: Regression \& Structural Equation Modeling; Statistical Associates Publishing: Asheboro, NC, USA, 2016.

51. Ali, F.; Kim, W.G.; Ryu, K. The effect of physical environment on passenger delight and satisfaction: Moderating effect of national identity. Tour. Manag. 2016, 57, 213-224. [CrossRef]

52. Henseler, J.; Ringle, C.M.; Sinkovics, R.R. The use of partial least squares path modeling in international marketing. In New Challenges to International Marketing; Emerald Group Publishing Limited: Bingley, UK, 2009; Volume 20, pp. $277-319$.

53. Hair, J.F.; Sarstedt, M.; Ringle, C.M.; Mena, J.A. An assessment of the use of partial least squares structural equation modeling in marketing research. J. Acad. Mark. Sci. 2012, 40, 414-433. [CrossRef]

54. Esposito Vinzi, V.; Chin, W.W.; Henseler, J.; Wang, H. Handbook of Partial Least Squares: Concepts, Methods and Applications; Springer: Berlin/Heidelberg, Germany, 2010.

55. Fornell, C.; Larcker, D.F. Evaluating structural equation models with unobservable variables and measurement error. J. Mark. Res. 1981, 18, 39-50. [CrossRef]

56. Chin, W.W. The partial least squares approach to structural equation modeling. Mod. Methods Bus. Res. 1998, 295, 295-336.

57. Barclay, C.; Thompson, D.; dan Higgins, R. The Partial Least Squares (PLS) Approach to Causal Modeling: Personal Computer Adoption and Use an Illustration. Technol. Stud. 1995, 2, 285-309.

58. Liu, Y. A new antihypertensive drug ameliorate insulin resistance. Acta Pharmacol. Sin. 2012, 33, 429-430. [CrossRef] [PubMed]

59. Kushary, D. Bootstrap Methods and their Application. Technometrics 2000, 42, 216-217. [CrossRef]

60. Akter, S.; D'Ambra, J.; Ray, P. An Evaluation of PLS based Complex Models: The Roles of Power Analysis, Predictive Relevance and GoF Index. In Proceedings of the Renaissance of Information Technology for Sustainability and Global Competitiveness, 17th Americas Conference on Information Systems (AMCIS 2011), Detroit, MI, USA, 4-8 August 2011.

61. Lleras, C. Path Analysis. Encycl. Soc. Meas. 2005, 3, 25-30. [CrossRef]

62. Aibinu, A.A.; Al-Lawati, A.M. Using PLS-SEM technique to model construction organizations' willingness to participate in e-bidding. Autom. Constr. 2010, 19, 714-724. [CrossRef]

63. Cohen, J.; Cohen, P.; West, S.G.; Aiken, L.S. Applied Multiple Regression/Correlation Analysis for the Behavioral Sciences; Routledge: London, UK, 2013.

64. Henseler, J.; Sarstedt, M. Goodness-of-fit indices for partial least squares path modeling. Comput. Stat. 2013, 28, 565-580. [CrossRef]

65. Wetzels, M.; Odekerken-Schröder, G.; Van Oppen, C. Using PLS path modeling for assessing hierarchical construct models: Guidelines and empirical illustration. MIS Q. 2009, 177-195. [CrossRef]

66. Taleai, M.; Amiri, E.T. Spatial multi-criteria and multi-scale evaluation of walkability potential at street segment level: A case study of tehran. Sustain. Cities Soc. 2017, 31,37-50. [CrossRef] 
67. Mitchell, R. Is physical activity in natural environments better for mental health than physical activity in other environments? Soc. Sci. Med. 2013, 91, 130-134. [CrossRef]

68. Sallis, J.F.; Johnson, M.F.; Calfas, K.J.; Caparosa, S.; Nichols, J.F. Assessing Perceived Physical Environmental Variables that May Influence Physical Activity. Res. Q. Exerc. Sport 1997, 68, 345-351. [CrossRef]

69. Villanueva, K.; Knuiman, M.; Nathan, A.; Giles-Corti, B.; Christian, H.; Foster, S.; Bull, F. The impact of neighborhood walkability on walking: Does it differ across adult life stage and does neighborhood buffer size matter? Health Place 2014, 25, 43-46. [CrossRef]

70. Bauman, A.E.; Smith, B.; Stoker, L.; Bellew, B.; Booth, M. Geographical influences upon physical activity participation: Evidence of a 'coastal effect'. Aust. N. Z. J. Public Health 1999, 23, 322-324. [CrossRef] [PubMed]

71. Wright, C.; MacDougall, C.; Atkinson, R.; Booth, B. Exercise in Daily Life, Supportive Environments. Report of a National Heart Foundation Research Project Funded by the Commonwealth Department of Health and Family Services; Commonwealth of Australia: Canberra, Australia, 1996.

72. Hawthorne, W. Why Ontarians Walk, Why Ontarians Don't Walk More: A Study of the Walking Habits of Ontarians; Energy Probe Research Foundation: Toronto, ON, Canada, 1989.

73. Geurs, K.T.; Van Wee, B. Accessibility evaluation of land-use and transport strategies: Review and research directions. J. Transp. Geogr. 2004, 12, 127-140. [CrossRef]

74. Heim, B.; Joosten, M.; Von Richthofen, A.; Rupp, F. Land-allocation and clan-formation in modern residential developments in Oman. City Territ. Arch. 2018, 5, 8. [CrossRef]

75. Larco, N.; Steiner, B.; Stockard, J.; West, A. Pedestrian-friendly environments and active travel for residents of multifamily housing: The role of preferences and perceptions. Environ. Behav. 2012, 44, 303-333. [CrossRef]

76. Ball, K.; Bauman, A.; Leslie, E.; Owen, N. Perceived environmental aesthetics and convenience and company are associated with walking for exercise among Australian adults. Prev. Med. 2001, 33, 434-440. [CrossRef]

77. Ewing, R.; Handy, S. Measuring the Unmeasurable: Urban Design Qualities Related to Walkability. J. Urban Des. 2009, 14, 65-84. [CrossRef]

78. Hooper, P.; Foster, S.; Bull, F.; Knuiman, M.; Christian, H.; Timperio, A.; Wood, L.; Trapp, G.; Boruff, B.; Francis, J. Living liveable? RESIDE's evaluation of the "Liveable Neighborhoods" planning policy on the health supportive behaviors and wellbeing of residents in Perth, Western Australia. SSM Popul. Health 2020, 10, 100538. [CrossRef]

79. Hakimian, P.; Lak, A. Adaptation and reliability of neighborhood environment walkability scale (NEWS) for Iran: A questionnaire for assessing environmental correlates of physical activity. Med. J. Islam. Repub. Iran 2016, 30, 427.

80. Cerin, E.; Sit, C.H.; Cheung, M.-C.; Ho, S.-Y.; Lee, L.-C.J.; Chan, W.-M. Reliable and valid News for Chinese seniors: Measuring perceived neighborhood attributes related to walking. Int. J. Behav. Nutr. Phys. Act. 2010, 7, 84. [CrossRef] [PubMed]

81. Malavasi, L.M.; de Fatima, S.D.M.; Both, J. Neighborhood Walkability Scale (news-Brazilian Version): Construct Validity Board. Med. Sci. Sports Exerc. 2007, 39, S189-S190. [CrossRef]

82. Hyunshik, K.; Younglae, C.; Jiameng, M.; Kuam Hyung, M.M.; Sunkyoung, L. The neighborhood environment walkability scale for the republic of Korea: Reliability and relationship with walking. Iran. J. Public Health 2016, 45, 1427.

83. Cervero, R.; Kockelman, K. Travel demand and the 3Ds: Density, diversity, and design. Transp. Res. Part D Transp. Environ. 1997, 2, 199-219. [CrossRef] 